\title{
TRANSFORMASI EKONOMI ISLAM DALAM SISTEM EKONOMI KERAKYATAN
}

\author{
Sugeng Riyadi dan Dewi Laela Hilyatin \\ Institut Agama Islam Negeri Purwokerto \\ Email: sugengriyadi@iainpurwokerto.ac.id dan dewilaelahilyatin@iainpurwokerto.ac.id
}

\begin{abstract}
A capitalist economic system that prioritizes individual interests, and a socialist economic system that prioritizes common interests cannot provide solutions to problems faced by society. Islamic economy as a developing solution in Indonesia which implements a populist economic system (based on Pancasila values) is still focused on financial institutions. This article is written to discuss the transformation of the Islamic economy in a populist economic system. The method used is the library research method. From the results of the discussion it can be concluded that there are 7 principles of synergy between Islamic economics and social economics, if the seven principles are implemented with due regard to the Indonesian context, Islam is not just a label, and considers maqashid sharia, community welfare will be realized. Islamic economic development is not only focused on financial institutions but also on the real sector.
\end{abstract}

Keywords: Transformation, Islamic Economy, and Social Economic.

\begin{abstract}
Abstrak
Sistem ekonomi kapitalis yang mengutamakan kepentingan individu, dan sistem ekonomi sosialis yang mengutamakan kepentingan bersama tidak dapat memberikan solusi atas permasalahan yang dihadapi masyarakat. Ekonomi Islam sebagai solusi berkembang di Indonesia yang menerapkan sistem ekonomi kerakyatan (berdasarkan nilai Pancasila) masih fokus pada lembaga keuangan. Artikel ini disusun untuk membahas transformasi ekonomi Islam dalam sistem ekonomi kerakyatan. Metode yang digunakan adalah metode penelitian pustaka. Dari hasil pembahasan dapat disimpulkan bahwa terdapat 7 prinsip sinergi antara ekonomi Islam dan ekonomi sosial, jika ketujuh prinsip tersebut dilaksanakan dengan memperhatikan konteks keindonesiaan, Islam tidak hanya sekedar label, dan mempertimbangkan maqashid syariah, kesejahteraan masyarakat akan terwujud. Pembangunan ekonomi Islam tidak hanya terfokus pada lembaga keuangan tetapi juga pada sektor riil.
\end{abstract}

Kata Kunci: Transformasi, Ekonomi Islam, dan Ekonomi Kerakyatan. 


\section{PENDAHULUAN}

Ekonomi sebagai sebuah ilmu yang mempelajarai tentang kebutuhan dan keinginan seseorang yang tidak terbatas dengan sumber daya terbatas. Hal ini mengharuskan mereka untuk memilih (choices) dan membuat skala prioritas untuk beberapa pilihannya sehingga dapat memberikan tingkat utilitas yang maksimal. Namun demikian ketika pilihan itu sudah dipilih dengan berbagai ikhtiar dan proses yang dilakukan, tidak semua orang dapat mendapatkan apa yang mereka pilih (kebutuhan atau keinginan), karena ada satu poin lagi yaitu opportunity cost.

Dalam kehidupan masyarakat dewasa ini, kegiatan ekonomi telah menjadi sedemikian rumit karena melibatkan berbagai macam sumber daya, baik sumber daya alam, sumber daya manusia, dan sumber daya uang. Sistem ekonomi kapitalis tumbuh dan berkembang dengan bersumber pada sumber daya keuangan, sehingga logika ekonominya berkembang dan berorientasi pada kepentingan pemilik modal. Sistem ini memiliki prinsip pasar bebas (pasar ditentukan oleh permintaan dan penawaran). Adanya persaingan bebas menyebabkan masyarakat yang bermodal besar semakin kuat bahkan jika sisi moral dikesampingkan, maka yang lemah akan semakin tertindas.

Ketidakpuasan masyarakat dengan adanya sistem ekonomi kapitalis, lahirlah ekonomi sosialis dengan prinsip setiap masyarakat memiliki hak yang sama atas faktor faktor produksi. Faktor produksi yang meliputi pengusaha, pekerja, modal, sumber daya alam dimiliki bersama oleh masyarakat dan diatur oleh negara. Peran pemerintah (negara) sangat kuat dan besar. Di satu sisi memang menumbuhkan sikap kebersamaan, ada istilah dalam bahas jawa "mangan ora mangan sing penting ngumpul". Prinsip yang dikedepankan adalah kebersamaan dan persamaan, sehingga tidak ada motivasi untuk berusaha, karena sebesar apapun mereka berusaha pada akhirnya hak yang diterima sama dengan mereka yang tidak melakukan apapun. Inilah yang menyebabkan sistem ekonomi sosialis runtuh dengan tumbangnya uni soviet pada 26 Desember 1991.

Indonesia, sebagai negara yang menganut sistem ekonomi kapitalis, mengalami krisis berkepanjangan yang sampai saat ini belum bisa dipastikan apakah Indonesia telah keluar dari krisis. Saat ini, berjuta-juta orang menganggur, puluhan juta orang berada di bawah garis kemiskinan, sektor moneter yang semakin jauh dari sektor riil sehingga berpotensi meledakkan bubble economicl yang sudah terbentuk, dan berbagai macam masalah melingkupi kehidupan perekonomian Indonesia.(Rizal, 2011).

Krisis moneter yang yang dialami Indonesia sedemikian parah, padahal banyak ahli ekonomi mumpuni yang kita miliki. Pada bulan Juli 1997 rupiah terdevaluasi hingga 30\% dan pada Juli 1998 (dalam setahun) rupiah sudah terdevaluasi hingga $90 \%$. Sehingga hal ini tidak hanya menimbulkan kekacauan di bidang moneter tetapi juga banyak bidang usaha yang gulung tikar.

Beberapa bank di Tanah Air tumbang akibat krisis moneter. Ketika itu, pemerintah terpaksa harus mengalirkan dana ratusan triliun dalam bentuk obligasi rekapitulasi ke hampir semua bank besar. Tetapi, masih ada bank, yang walaupun sedikit terguncang, berhasil selamat dari krisis. Bahkan, tanpa bantuan uang negara sedikitpun. Salah satunya, yaitu Bank Muamalat Indonesia Tbk. Bank murni syariah pertama di Indonesia itu selamat dari krisis bukan tanpa sebab. Bank Muamalat dinilai lebih tahan guncangan karena sistem syariah yang dianut mengharamkan perusahaan dari aksi spekulasi, yang digadang-gadang sebagai penyebab krisis keuangan (Agustiyanti \& Safyra Primadhyta, 2018, diakses 16 Oktober 2020).

Dari sinilah sistem Ekonomi Islam yang lebih dikenal dengan ekonomi syariah mulai berkembang di Indonesia. Perkembangannya cukup pesat meskipun masih terbatas pada industri keuangan 
(finance industry), sehingga seringkali ekonomi syariah dipahami dan diidentikkan dengan industri jasa keuangan. Bentuk lembaga keuangan terdiri dari: bank umum, bank perkreditan rakyat, asuransi, pasar modal, multi-finance, lembaga keuangan mikro dan koperasi.

Pertumbuhan ekonomi syariah di indonesia cukup baik dibandingkan lembaga konvensional salah satunya dengan pertumbuhan perbankan syariah $10,14 \%$, dibandingkan dengan bank konvensional yang hanya 3,04\% \{https://finansial.bisnis.com/\}. Berdasarkan data Otoritas Jasa Keuangan (OJK), hingga Juli 2020 nilai aset keuangan syariah sebesar $\mathrm{Rp} 1.639,08$ triliun atau naik 20,61\% secara year on year (yoy). Sementara pangsa pasar keuangan syariah mencapai 9,68\%. Hal ini didukung dengan semakin banyaknya jumlah lembaga jasa keuangan syariah mulai dari sektor perbankan terdapat 14 bank umum syariah, 20 UUS dan 162 BPRS. Kemudian sektor pasar modal memiliki 464 saham syariah, 145 sukuk korporasi, 282 reksadana syariah dan 66 sukuk negara. (Mediatama, 2020).

Berdasarkan data Otoritas Jasa Keuangan (OJK), market share dari keuangan syariah terhadap sistem keuangan di Indonesia per April 2020 mencapai 9,03\% dengan total aset keuangan syariah Indonesia-tidak termasuk saham syariahmencapai Rp1.496,05 triliun. Pangsa pasar ini mengalami kenaikan dari posisi 2019 yang sebesar $8 \%$. Presiden Direktur BCA Syariah John Kosasih mengatakan perbankan konvensional masih tetap dominan dengan market share sekitar 94\%. Meskipun pertumbuhan perbankan syariah dua kali lipat dari industri, market share syariah tetap tidak bisa mengalahkan konvensional. (Pangsa Pasar Keuangan Syariah Sulit Imbangi Kinerja Konvensional Finansial, 2020).

Hal ini menunjukkan walapun lembaga keuangan syariah tumbuh dengan cukup pesat, namun masih sulit untuk pemberdayaan ekonomi nasional. Oleh karena itu sebelum mengidealkan peran yang strategis dalam perekonomian nasional, tantangan perbankan dan lembaga keuangan syariah non bank harus difokuskan pada upaya memperluas pangsa pasar. Upaya tersebut menjadi penting sebab perkembangan bank syariah dan lembaga keuangan syariah non bank akan ditentukan oleh aspek ekspansi finansial (financial expantion). Persoalan utama dalam perkembangan lembaga keuangan syariah adalah: kelangkaan modal, terbatasnya kapasitas kelembagaan, sumber daya yang profesional.(Rahardjo, 2015: 307).

Kelangkaan modal yang dihadapi karena terbatasnya sumber permodalan domestik. Sedangkan dari sisi pengembangan kapasitas kelembagaan terkait dengan kompatibilitas produk industri keuangan yang khas dengan nuanasa maqashid syariah dan compliance terhadap prinsip syariah. Permasalahan sumber daya yang profesional karena belum tersedianya sumber daya baik secara kuantitas maupun kualitas. Namun demikian pemenuhan kebutuhan SDM yang profesional sudah mulai diatasi dengan munculnya berbagai industri pendidikan dan pelatihan di bidang keuangan syariah.

Peranan strategis ekonomi syariah yang ditandai dengan tumbuhnya lembaga keuangan syariah sebenarnya sangat ditentukan oleh strategi pembangunan nasional Indonesia. Menurut Aburizal Bakrie ketika menjabat sebagai KADIN mengatakan bahwa masalah perekonomian nasional yang paling mendasar sebenarnya dapat diatasi dengan pengembangan usaha mikro, kecil dan menengah atau ekonomi rakyat yang mencakup $99 \%$ dari keseluruhan perekonomian nasional (Rahardjo, 2015: 308). Oleh karena itu seharusnya pengembangan ekonomi syariah di Indonesia diarahkan pada pengembangan ekonomi rakyat, tidak hanya fokus pada industri keuangan.

Berdasarkan permasalahan di atas penulis tertarik untuk membahas lebih lanjut dalam makalah yang berjudul "Transformasi 
Ekonomi Syariah Dalam Sistem Ekonomi Kerakyatan". Untuk memberikan batasan masalah dalam makalah ini, maka beberapa rumusan masalah yang akan dibahas yatiu: rancang bangun ekonomi Islam, sistem ekonomi kerakyatan, dan transformasi ekonomi Islam dalam sistem ekonomi kerakyatan. Adapun untuk penulisan makalah ini metode yang digunakan adalah metode pustaka (library research) dengan pendekatan deskriptif analisis. Diharapkan dengan penulisan makalah ini dapat memberikan wawasan dan menambah khazanah keilmuan bagi penulis dan pembaca tentang ekonomi Islam dalam sistem ekonomi kerakyatan khususnya di Indonesia.

\section{LITERATURE REVIEW}

Penelitian tentang ekonomi Islam dalam sistem ekonomi kerakyatan sudah pernah dilakukan oleh Suhendi dengan judul Ekonom Islam Berbasis Ekonomi Kerakyatan (Suhendi, 2012: 299). Dijelaskan bahwa pelaksanaan ekonomi yang berlandaskan ekonomi Islam bersifat adil, memiliki keberpihakan pada ekonomi kerakyatan, karena tujuannya adalah kesejahteraan semua masyarakat. Perkembangan ekonomi dan bisnis Syariah di Indonesia memiliki konsekuensi kebutuhan SDM yang memahami ekonomi Islam. Ekonomi Syariah menekankan 4 prinsip dan sifat dasar yaitu: Kesatuan (unity), Keseimbangan (equilibrium), Kebebasan (free will), dan Tanggungjawab (responsibility). Manusia sebagai khalifatullah tidak mungkin bersifat individualistic. Untuk itu orientasi Ekonomi Islam selalu diarahkan pada kepentingan masyarakat kecil atau menyentuh pembangunan ekonomi kerakyatan (masyarakat aktif dalam meningkatkan penghasilannya).

Dalam penelitian Sofyan Rizal dengan judul titik temu dan sinergi ekonomi Islam dan ekonomi kerakyatan (Rizal, 2011: 1), bahwa ekonomi Islam dan ekonomi kerakyatan sesungguhnya mempunyai tujuan yang sama, yaitu kesejahteraan dan keadilan bagi semua orang. Menurut Islam, keadilan dan kesejahteran dalam kehidupan ekonomi harus berlandaskan norma dan etika Islam, sehingga semua sistem ekonomi tersebut berjalan sesuai dengan syariat Islam. Ekonomi kerakyatan di Indonesia telah ada sejak lama dengan institusinya yaitu koperasi. Pada tataran konsep dan pelaksanaan, koperasi memiliki banyak kesesuaian dengan institusi pemberdayaan ekonomi harapanslam.

Penelitian lain tentang ekonomi kerakyatan dilakukan oleh Siti Muallimah yang berfokus pada konsep ekonomi kerakyatan Mohammad Hatta dalam tinjauan Maqashid Syari'ah (Muallimah, 2018: 68). Hatta terdorong untuk mengembangkan koperasi karena perhatiannya terhadap rakyat yang tertindas oleh struktur sosial-ekonomi pada zaman kolonial Belanda yang didukung oleh kaum aristokrat dalam sistem feodalisme Jenis penelitian ini adalah penelitian kepustakaan (library research). Menggunakan sumber primer dan sekunder. Berdasarkan hasil penelitian dan pembahasan disimpulkan bahwa: koperasi merupakan konsep ekonomi kerakyatan. Koperasi adalah bentuk usaha bersama rakyat untuk mencapai tujuan bersama. Bentuk ekonomi kerakyatan dalam bentuk koperasi sebagaimana tercermin dalam pasal 33 UUD 1945. Relevansi pemikiran Hatta dengan tujuan agama Islam (Maqașid alsyari'ah) diantaranya adalah: nilai dasar kepemilikan, keadilan, kebersamaan dan kekeluargaan, kerjasama ekonomi dan koperasi, demokrasi ekonomi dan peran pemerintah.

Sejauh pembacaan penulis terhadap penelitian dan artikel terdahulu belum ada yang membahas terkait transformasi nilai nilai ekonomi Islam dalam system ekonomi kerakyatan, oleh karena itu kajian tentang hal ini menarik dan perlu untuk ditulis.

\section{METODE PENELITIAN}

Penulisan artikel ini menggunakan metode studi Pustaka pendekatan deskriptif 
kualitatif. Data primer yang digunakan dalam penelitian ini yaitu data yang diambil dari referensi referensi yang terkait dengan tema pembahasan, baik dari buku dan jurnal. Sedangkan teknik pengumpulan datanya menggunakan teknik dokumentasi dan studi pustaka.

\section{KONSEP DASAR}

\section{Rancang Bangun Ekonomi Islam}

Untuk melihat design atau rancangan ekonomi Islam ada beberapa hal yang harus dipahami yaitu: pengertian ekonomi Islam, prinsip ekonomi Islam, dan aliran madzhab pemikiran ekonomi Islam.

Ekonomi berasal dari bahasa latin oikosnomos yang diperkenalkan oleh ahli filasat Aristoteles pada zaman Yunani Kuno. Oikos berarti rumah tangga, sedangkan nomos berarti "ilmu". Ilmu ekonomi adalah kajian tentang produksi, distribusi dan konsumsi yang dilakukan oleh individu yang tinggal dalam satu keluarga (rumah tangga).

Karena ekonomi adalah kajian ilmiah maka dalam memahami dan membahasnya ada tiga tahapan proses yaitu: ontologi (keberadaan), epistemologi (bagaimana), dan aksiologi (nilai guna, hasil, tujuan). Dalam kajian ontologi berarti membahas apa masalah yang dihadapi dalam kehidupan ini terkait produksi, distribusi dan konsumsi. Jika dihubungkan dengan epistemologi berarti cara manusia untuk menyelesaikan masalah yang dihadapi dalam memenuhi kebutuhan. Sedangkan aspek aksiologi definisi tersebut mencakup tujuan kegiatan ekonomi yakni untuk memenuhi kebutuhan hidup.

Pemahaman tentang ekonomi Islam sebagaimana dijelaskan oleh sjafruddin Prawiranegara sama dengan ekonomi konvensional. Tidak ada pengertian tersendiri antar keduanya karena yang membedakan adalah bahwa ekonomi Islam menurut teknokrat tahun 1950an didasarkan pada ajaran moral Islam.(Prawiranegara, 1988).
Dalam buku An Integral Approach to Development Economics dijelaskan bahwa makna ekonomi Islam: (Oshodi, 2013: 150).

"The Islamic economic system is thus based on eliminating interest, uncertainty, gambling and unethical concerns while promoting justice and fairness in a trans-cultural and transdisciplinary manner, in an integral dynamic (Lessem and Schieffer 2013) covering time and space. It seeks to promote a system founded on moral sentiment, love and sincerity; on production, labour and capital, and on the peaceful co-existence of all'".

System ekonomi Islam adalah melarang pelaku ekonomi untuk melakukan transaksi yang mengandung unsur seperti bunga, spekulasi, judi, dan beberapa hal yang tidak beretika sesuai dengan nilai nilai Islam. Sampai saat ini ada definisi ekonomi Islam yang biasa dirujuk, pendapat Hasanuzzaman: ilmu ekonomi Islam adalah pengetahuan tentang penerapan perintah (injuctions) dan tata cara (rules) yang ditetapkan syariat untuk mencegah ketidak adilan dalam peggalian dan penggunaan sumber daya untuk memenuhi kebutuhan manusia, dalam rangka melaksanakan kewajiban kepada Allah.

Definisi yang kedua adalah gagasan Mohammad Arkham Khan, bahwa ekonomi Islam bertujuan melakukan kajian keberhasilan manusia (human falah) yang dicapai dengan mengelola sumber daya berdasar prinsip gotong royong (Rahardjo, 2015: 130). Setelah memaknai ilmu ekonomi Islam, selanjutnya yang masih dalam pembahasan adalah penggunaan ekonomi Islam atau ekonomi syariah. Karena ada kekhawatiran jika ekonomi Islam diidentikkan dengan ekonomi syariah yang kelembagaannya adalah industri keuangan, pemikiran ekonomi Islam akan menuai jalan buntu, dimana hanya dilakukan untuk tujuan bisnis yang mencari keuntungan. Dari sinilah muncul ide untuk diarahkan pada doktrin almaqashid al-syari'ah sebagai doktrin kesejahteraan Islam. 
Al-maqashid al-syari'ah menurut alGhazali adalah meningkatkan kesejahteraan seluruh manusia yang terletak pada perlindungan keimanan (hifdzu ad-din), jiwa (hifdzu an-nafs), akal (hifdzu al-'aql), keturunan ( (hifdzu al-nasl) dan kekayaan ((hifdzu al-mal) mereka. Apapun yang menjamin kelima hal ini menjamin kepentingan publik dan merupakan hal yang diinginkan (Chapra, 2001: 124) bawah ini:

Hal ini senada dengan pernyataan di

"The Islamic moral economic system is based on fiqh al-muamalat - Islamic commercial jurisprudence derived from the Shariah, Islamic law: The very objective of the Shariah is to promote the wellbeing of the people, which lies in safeguarding their faith (din), their self (nafs), their intellect (aql), their posterity (nasl), and their wealth (mal). Whatever ensures the safeguard of these five serves public interest and is desirable, and whatever hurts them is against public interest and its removal is undesirable. This system seeks to promote a moral, socio-economic system that eliminates undue profits in business transactions and a bias-fee social structure." (Baswir, 2015: 96)

Bahwa Sistem ekonomi moral Islam didasarkan pada fiqh al-muamalat (bersumber dari Syariah Islam). Tujuan utama dari Syariah adalah mengutamakan kesejahteraan masyarakat, dengan cara menjaga keimanan mereka (din), mereka diri (nafs), akal (aql), keturunan (nasl), dan harta (mal). Apa pun yang menjamin perlindungan kelima hal ini untuk kepentingan publik dan apapun yang merugikan bertentangan dengan kepentingan public. Sistem ini berusaha mengedepankan moral, social ekonomi, menghilangkan konsep bisnis hanya untuk mencari keuntungan.

Sebagaimana keragaman definisi mengenai ekonomi Islam, sebenarnya ada dua esensi atau hakikat ekonomi Islam.

a. Ekonomi Syariah: ilmu ekonomi yang didasarkan pada hokum Syariah, khususnya muamalat. b. Ekonomi Islam: esensi ekonomi Islam adalah etika atau nalar moral yang mendasari perilaku manusia dalam melakukan kegiatan ekonomi (moral science).

Dalam tulisan Hafas Furqani dalam membangun ilmu ekonomi Islam dengan tipologi ilmiah. Tipologi itu adalah:(Furqani, 2016: 84-89)

a. Metodologi fikih (ușhul al-fiqh): Obyek kajian fikih dan ekonomi berbeda, fikih membahas hukum perilaku manusia, sedangkan ekonomi mengkaji perilaku manusia yang cakupannya lebih luas tidak sekedar hukum. Metodologi fikih tidak cukup dalam memahami realitas ekonomi yang sangat dinamis. Metodologi fikih dan ekonomi memiliki tujuan yang berbeda.

b. Metodologi pluralisme: artikulasi ekonomi Islam menggunakan berbagai metodologi, karena ekonomi Islam butuh metodologi yang fleksibel dan dinamis. Metode ini berdasar pada epistemology Islam yang mengakui berbagai sumber ilmu (pengetahuan dan teori dapat dilahirkan). Menggunakan berbagai sumber ilmu dan metodologi untuk mengungkap kebenaran yang hakiki (kebenaran obyektif, kebenran logis, dan kebenaran wahyu). Berbagai metode tersebut tidak saling bertentangan akan tetapi saling melengkapi.

c. Metodologi Islamisasi ilmu pengetahuan yang mencoba melakukan interaksi dan integrasi metodologi ilmu ekonomi dan metodologi yang terdapat dalam ilmuilmu Islam. Metodologi Islamisasi ekonomi Islam menggunakan body of knowledge atau metodologi ekonomi konvensional yang dianggap baik dan sesuai dengan prinsip Islam. Dalam merevisi teori ekonomi konvensional, ada dua cara yang dapat dilakukan menurut Kahf yaitu: takhliya (mengidentifikasi dan mengisolasi poustulat ekonomi yang dianggap tidak sesuai dengan prinsip Islam); Tahliya (memasukkan postulat ekonomi baru yang digali dari prinsip 
Islam) in order to revise the conventional economic theo ries.(Kahf, 2003: 23-47).

Dalam rancang bangun ekonomi Islam, setelah mendefinisikan ekonomi Islam, berikutnya adalan menjelaskan prinsip prinsip ekonomi Islam. Ekonomi Islam memiliki dua dimensi yaitu dimensi material dan non material. Prinsip dasar yang dibangun dalam ekonomi Islam ada lima: tauhi, adil, dan keseimbangan, kehendak bebas, dan bertanggungjawab (Naqvi, 1981: 21).

Konsep tauhid tidak hanya tercermin dalam hubungan vertikal (manusia dengan Sang Pencipta) tetapi juga hubungan horisontal. Sebagai refleksi dari prinsip ini adalah:

a. Tidak mendiskriminasi orang lain pertimbangan ras, warna kulit, gender, agama, dan lainnya.

b. Tidak melakukan praktik yang tidak etis

c. Tidak menimbun kekayaan (iktinaz), menggunakan petunjuk Allah Swt.

Prinsip keadilan merupakan ajaran fundamental yang mencakup keseluruhan aspek kehidupan: ekonomi, sosial, politik, bahkan lingkungan hidup. Adil menurut Abdurrahman Wahid dalam makalahnya yang berjudul "Konsep-konsep Keadilan" dimaknai: benar, tidak memihak, penjagaan hak-hak seseorang, cara yang tepat dalam mengambil keputusan, keseimbangan, dan pemerataan.(Rachman, 1994: 76)

Prinsip Keseimbangan, seimbang berarti kita bersikap moderat. Tidak berlebihan dalam menyikapi atau memposisikan segala sesuatu. Seimbang dalam memenuhi kebutuhan dunia dan akhirat.(Akhmadi \& Kholish, 2016: 108)

Prinsip kebebasan yang dimaksud kebebasan yang dibingkai dengan tauhid artinya bebas dengan batasan yang telah diatur oleh Allah dalam Al-Quran. Prinsip ini merupakan unsur pelengkap dalam konsep "khilafah". Karena sampai tingkat tertentu manusia dianugerahi kehendak bebas (free will) untuk mengarah dan membimbing kehidupannya sendiri sebagai khalifah di bumi (Beekun, 1997: 14-16). Dibekalinya potensi berupa akal oleh Allah dapat diaplikasikan oleh manusia sebagai khalifah untuk berfikir kritis

Prinsip pertanggungjawaban, prinsip ini merupakan penyerta dari kebebasan. Refleksi adanya tanggung jawab ini, bahwa setiap tindakan manusia pasti ada balasan dan konsekuansinya. Jika manusia memiliki kebebasan dalam memiliki harta tertentu, maka pertanggungjawabannya meliputi: bagaimana mereka mendapat harta tersebut dan bagaimana mereka memanfaatkannya, dan apakah harta tersebut dimanfaatkan dengan melanggar syariat Islam atau tidak.

Dalam perkembangannya ada tiga alilran pemikiran ekonomi Islam yang berkembang. Dalam buku Ekonomi Makro Islam Adiwarman Karim, disebutkan ada tiga aliran pemikiran ekonomi Islam(Karim, 2003):

Madzhab Iqtishaduna: aliran ini menjelaskan bahwa keinginan dan kebutuhan mannusia terbatas, sedangkan sumber daya (alat pemenuh kebutuhan) tidak terbatas. Karena menurut aliran ini bahwa Allah sudah menciptakan segala sesuatu tepat dan sesuai dengan yang dibutuhkan. Permasalahannya ada pada pengelolaan dan distribusi yang tidak tepat oleh pelaku ekonomi.

Madzhab mainstream: aliran ini yang banyak diikuti oleh pemikir ekonomi Islam kontemporer. Bahwa keinginan dan kebutuhan manusia tidak terbatas, sedangkan sumber daya terbatas. Sebagaimana yang dijelaskan dalam hadits Rasulullah "manusia ketiga diberi 1 gunung emas meminta 2, ketika diberi 2 meminta 3, dan seterusnya mereka tidak pernah puas". Hal ini sejalan dengan apa yang dijelaskan dan teori ekonomi konvensiona. Akan tetapi menurut aliran ini bahwa variable variable yang ada di dalam teori konvensional tidak sepenuhnya salah, dan apabila ada yang tidak sesuai dengan nilai dan prinsip Islam maka itulah yang diganti.

Madzhab alternative kritis, sebagai madzhab aliran pemikiran ekonomi Islam yang dicetuskan oleh Timur Quran. Madzhab ini mengkritisi kedua madzhab sebelumnya. 
Menurutnya bahwa madzhab iqtishaduna hanya menyalahkan atau membuat teori yang selalu berlawanan dengan teori konvensional. Sedangkan pendapatnya untuk aliran mainstream, bahwa aliran ini hanya mengubah sedikit variabel (menambah atau mengurangi) teori ekonomi konvensional.

Selain pembagian madzhab di atas, Dawam Rahardjo membagi aliran ekonomi Islam menjadi 4 (Rahardjo, 2015: 142) yaitu pertama, aliran syariat yang memandang ekonomi Islam sebagai pelaksanaan hokum syariat di bidang ekonomi atau pengelolaan sumber daya ekonomi. Dalam aliran ini ekonomi dipandang sebagai fikih muamalat sebagaimana yang dijelaskan oleh Ibnu Rusyd seorang fuqaha pengarang kitab "Bidayah Al-Mujtahid".

Kedua, melihat ekonomi Islam sebagai moral ekonomi, pemikiran ini mengacu pada pemikiran al-Ghazali dan Ibnu Taimiyah dalam wacana Teologi Ekonomi. Teori ini juga dikembangan oleh Heider Naqvi dalam karyanya yang mengingatkan kita pada buku Amitai Etzioni yang berjudul "Moral Dimension of economics (1983)".

Ketiga, aliran historis sosiologis yang melihat ekonomi Islam sebagai ilmu normatifsekaligus positif. Mengacu pada pemikiran Ibnu Khaldun dalam Kitab Muqaddimah.Keempat, aliran ekonomi politik yang dikembangkan oleh Abdurrahman Al-Maliki dalam bukunya "alSiyasah al-Iqtishadiyatuhu al-Mutsla”.

\section{Nilai Nilai Pancasila dalam Ekonomi Kerakyatan}

Ekonomi kerakyatan adalah suatu sistem yang dilakukan oleh rakyat, untuk rakyat, dan ditujukan sepenuhnya untuk kepentingan rakyat. Ekonomi rakyat secara harfiah dilahirkan oleh ahli-ahli ekonomi Indonesia sebagai usaha untuk menggali potensi ekonomi rakyat Indonesia melalui system ekonomi alternatif yang sebenarnya sudah dijalankan oleh rakyat. Secara praktik, ekonomi kerakyatan sudah dijalankan oleh rakyat sebelum kata ekonomi kerakyatan itu lahir (Mubyanto, 2002).
Jika melihat sejarah sebenarnya ekonomi kerakyatan sudah ada sebelum masa kemerdekaan yang tercermin dalam pemikiran Moh.Hatta. pemikiran Hatta tentang terpuruknya perekonomian masyarakat pribumi karena ekonomi dikuasai oleh masyarakat non pribumi (penjajah). Alternative yang digagas oleh bung hata adalam pengembangan ekonomi rakyat melalui koperasi.(Arief, 2001: 23)

Ekonomi Kerakyatan sering disebut sebagai konsep yang bersifat normatif, yaitu ekonomi yang berorientasi pada nilai-nilai Pancasila. Secara umum tujuan sistem ekonomi kerakyatan adalah keadilan sosial atau masyarakat yang adil dan makmur. Namun bagaimana bentuk masyarakat yang berkeadilan sosial atau adil dan makmur harus dirumuskan. Makna keadilan sosial bahwa masyarakat memiliki hak yang sama untuk mendapatkan akses terhadap faktor produksi. Sifat dari ekonomi rakyat sendiri adalah moralistik, demokratik, dan mandiri (Malau, 2016: 4).

Moralistis berarti bahwa segala tindakan ekonomi yang dilakukan berdasarkan pada etika. Walaupun dalam dunia bisnis tetap ada persaingan, tetapi persaingan yang ada tidak mendzalimi orang lain. Demokartik berarti bahwa masyarakat (rakyat) memiliki kebebasan dalam mengaksess sumber daya yang dimiliki negara, tentunya kebebasan di sini tetap disertai dengan rasa tanggungjawab. Mandiri adalah sikap dan sifat masyarakat tidak selalu bergantung pada orang lain dalam segala hal, rakyat diberikan motivasi bahwa sesungguhnya mereka mampu melakukan tugas dan tanggungjawab masing masing.

Ismawan menambahkan karakteristik yang dimiliki ekonomi rakyat berdasar dari jenis kegiatan yang dimaksud.antara lain: informalitas, mobilitas, kekeluargaan dan kemandirian (Ismawan, 2002). Informalitas berart bahwa ekonomi kerakyatan mayoritas berjalan di luar kerangka hukum. Adanya kelemahan dalam aturan ekonomi atau ketidakmampuan pemerintah untuk membuat sistem, akhirnya menggunakan sistem yang 
ada (dan seringkali dianggap tidak memihak usaha kecil dan rakyat). Hal ini melatarbelakangi ekonomi kerakyatan berkembang dengan subur (dengan atau tanpa aturan). Namun ini memberikan dampak negatif, karena dengan sifatnya yang informal menyebabkan terbatasnya akses permodalan baik pada lembaga keuangan formal seperti pebankan atau bantuan pemerintah. Akibatnya kadangkala sektor informal harus berhubungan dengan Lembaga keuangan nonformal (rentenir/ bank "thithil" yang berbunga sangat tinggi. Tampaknya karakteristik informal ini sebagai usaha inovatif masyarakat untuk mengatasi masalah permodalan dalam memulai usaha. Selain itu sebagai usaha unti mengatasi hambatan birokrasi karena terbatasnya akses informasi masyarakat tentang aturan-aturan usaha.

Aspek mobilitas memiliki makna mudah berubah, berpindah dan bergerak. Dengan sifat informalnya dan adanya faktor eksternal yang berpengaruh secara langsung dan cepat membawa konsekuensi bagi masyarakat, konsekuensi tersebut adalah tidak adanya jaminan keberlangsungan kegiatan ekonomi. Keluar masuk pasar menjadi sesuatu yang mudah dilakukan, misal terdapat peluang di pasar untuk membuka usaha tertentu masyarakat akan berbondong bondong terjun ke pasar. Jika dirasa bahwa pasar sudah tidak lagi menguntungkan untuk usaha tersebut, masyarakat akan meninggalkannya. Karakteristik ini dikecualikan untuk usaha di sektor pertanian dan perikanan (Rizal, 2011: $6)$.

Kemandirian merupakan kerakteristik ekonomi kerakyatan yang berkembang dan dipersepsikan oleh masyarakat, pemerintah atau pelaku ekonomi. Karenanya dalam praktiknya beberapa pihak masih membatasi diri dari system ekonomi kerakyatan ini. Ekonomi kerakyatan masih dianggap sektor yang berisiko dan tidak bankable (tidak layak mengakses pembiayaan perbankan). Karena system ini masih dianggap sebagai sektor penanggulangan kemiskinan, pemberdayaan usaha mikro, kecil dan menengah sehingga masih dikerjakan kurang maksimal. Perlakuan inilah yang kemudian mendorong ekonomi kerakyatan menjadi mandiri.

Memahami ekonomi kerakyatan dengan pendekatan ilmu filsafat berarti melihatnya dari sisi ontologi, epistemology dan aksiologi. Ekonomi kerakyatan dengan asumsi ontology, bahwa pelaku ekonomi kerakyatan adalam manusia secara utuh yang dapat mencapai tahap aktualisasi dini yang tinggi sebagai makhluk. Manusia seimbang dalam segala aspek: material-non material, individual- social.

Masalah epistemology dalam memahami ekonomi kerakyatan menyangkut metode dan praktik dari system ini. Supaya ideal maka perlu untuk mengkorelasikan ilmu ekonomi dengan ilmu yang lain. Berbicara masalah korelasi keilmuan dalam memahami kajian obyek tertentu ada beberapa cara: interdisipliner, transdisipliner, dan multidisipliner.

Interdisipliner merupakan metode untuk memahami satu obyek kajian dengan melibatkan beberapa orang yang memiliki keahlian yang berbeda beda tetapi masih satu rumpun keilmuan (beberapa orang dengan keahlian berbeda yang satu rumpun keilmuan mengkaji 1 objek) (Rohmatika, 2019: 7). Transdisipliner adalah metode memahami satu obyek yang dilakukan oleh satu orang dengan latar belakang beberapa keahlian. Sedangkan multidisipliner metode mengkaji satu obyek kajian dari sudut pandang keilmuan yang berbeda beda (yang relevan).

Berikut akan lebih diperinci ciri ciri sistem ekonomi kerakyatan yaitu:

1. Berdasar atas azas kekeluargaan; mengembangkan koperasi (Pasal 33 ayat 1).

2. Hal terkait hajat hidup orang banyak dikuasai oleh negara; mengembangkan BUMN (Pasal 33 ayat 2).

3. Pengelolaan dan pengawasan dalam pemanfaatan bumi, air, dan segala kekayaan yang terkandung di dalamnya 
untuk kemakmuran rakyat (Pasal 33 ayat 3).

4. Menjaga stabilitas perekonomian melalui kebijakan fiscal dan moneter.

5. Memastikan setiap warga negara memperoleh haknya untuk mendapatkan pekerjaan dan penghidupan yang layak (Pasal 27 ayat 2).

6. Memelihara fakir miskin dan anak terlantar (Pasal 34). (Baswir, 2015: 4-5)

Karakteristik atau ciri ciri sistem ekonomi kerakyatan di atas sejalan dengan apa yang disebutkan sebelumnya bahwa ekonomi kerakyatan berorientasi pada nilai pancasila. Pancasila yang terdiri dari lima sila, apabila diinternalisasi dan inetrkoneksikan dengan ekonomi kerkayatan mengandung maksud:

1. Nilai ketuhanan: sistem ekonomi berjalan dengan berpedoman pada nlai agama dan etika.

2. Kemanusiaan, sistem ekonomi mengedepankan prinsip humanis dan tidak eksploitatif.

3. Persatuan, setiap kegiatan ekonomi dilakukan bersama dengan berdasar pada azaz kekeluargaan

4. Musyawarah dan demokrasi, sistem ekonomi selaras dengan nilai demokrasi (dari rakyat dan untuk rakyat).

5. Keadilan, nilai ini mengandung makna pengelolaan sumber daya dan pendistribusiannya diatur sedail mungkin untuk kesejahteraan rakyat.

Ekonomi kerakyatan memiliki lima sasaran pokok yaitu:(Malau, 2016: 4)

1. Ketersediaan penghidupan yang layak dan peluang kerja untuk seluruh masyarakat.

2. Sistem jaminan sosial bagi anggota masyarakat yang membutuhkan, terutama fakir miskin dan anak-anak terlantar dapat terselenggara.

3. Kepemilikan modal (material) terdistribusi kepada anggota masyarakat secara merata.

4. Pendidikan nasional dapat terselenggara secara cuma-cuma bagi setiap masyarakat.
5. Kemerdekaan setiap anggota masyarakat untuk mendirikan dan menjadi anggota serikat ekonomi terjamin.

Berbicara mengenai pembangunan ekonomi tidak bisa dipisahkan dengan nilainilai moral kemanusiaan dan juga ekonomi kerakyatan. Ekonomi kerakyatan sendiri adalah ekonomi humanistik yang mendasarkan pada tercapainya kesejahteraan rakyat secara luas. Pembangunan ekonomi juga harus mendasarkan pada kemanusiaan dan menghindarkan diri dari persaingan bebas dan penindasan manusia satu dengan yang lainnya. Oleh karena itu, pembangunan ekonomi harus berpijak pada nilai moral dari Pancasila.(Malau, 2016: 3).

Sebagai sebuah landasan sistem ekonomi, ekonomi kerakyatan memiliki Keunggulan dan Kelemahan. Keunggulan ekonomi kerakyatan adalah: rakyat terlindungi dari persaingan yang tidak sehat, mampu meningkatkan kesejahteraan rakyat, memperkecil kesenjangan antara si Kaya dengan si Miskin, dan menciptakan hubungan sinergis antara Pemilik Modal Besar dengan Masyarakat sebagai mitra kerjan. Selain itu sebagaimana dijelaskan pada karakteristis ekonomi kerakyatan sub bagian mobilitas, bahwa karakteristik ini merupakan suatu keunggulan karena dapat dengan cepat dan inovatif merespon sebuah perubahan. Sedangkan kelemahan sistem ini adalah kurang diminati para pemilik modal besar karena keuntungan mereka perlu berbagi secara proporsional dengan masyarakat (Malau, 2016: 5).

\section{PEMBAHASAN DAN DISKUSI}

\section{Sinergi Ekonomi Islam dan Ekonomi Kerakyatan, Sebuah Transformasi Sistem dan Lembaga}

Ada 4 variabel yang akan coba dibahas dalam subbab berikut ini yaitu: sinergi, transformasi, ekonomi Islam dan ekonomi kerakyatan. Sinergi berarti kegiatan gabungan, penggabungan. Sinergi berasal dari bahasa Yunani synergos yang berarti bekerja bersama. Bentuk dari sebuah proses atau interaksi yang menghasilkan 
keseimbangan yang harmonis sehingga bisa menghasilkan sesuatu yang optimal. Ada beberapa syarat utama penciptaan sinergi yakni kepercayaan, komunikasi yang efektif, feedback yang cepat, dan kreativitas (Rustiono, 2020).

Sinergi di sini tidak termasuk kerjasama dalam arti bekerja sendiri-sendiri secara mandiri tanpa ada hubungan fungsional dan struktural, melainkan kerjasama dalam arti membangun sistem kerja yang efisien dan efektif berkat adanya hubungan fungsional antara satu sub sistem dengan sub sistem lainnya. Inilah yang disebutkan di dalam satau qaul: Al-Ittihad yujad al-quwwah (sinergi mendatangkan kekuatan). Inti sinergi sesungguhnya memanfaatkan perbedaan, bukannya mentolerir

perbedaan

apalagi mempertentangkannya.

Sedangkan transformasi dalam kamus Bahasa Indonesia diartikan dengan perubahan bentuk, rupa, dengan menambah atau mengurangi unsur unsur yang ada dalam sebuah system.(Arti kata transformasi Kamus Besar Bahasa Indonesia (KBBI) Online, 2020)

Dari makna sinergi dan transformasi serta kajian ekonomi Islam dan ekonomi kerakyatan, maka pembahasan kali ini akan dibagi menjadi dua kajian yaitu:

1. Sinergi ekonomi Islam dan Ekonomi Kerakyatan sebagai bentuk transformasi system. Berikut akan dijelaskan bagan untuk menggambarkan sinergi ekonomi Islam dan ekonomi kerakyatan dalam mewujudkan kesejahteraan masyarakat:

\section{Nilai rancang bangun ekonomi islam: Ketauhidan, keadilan, keseimbangan, kebebasan, tanggungjawab}

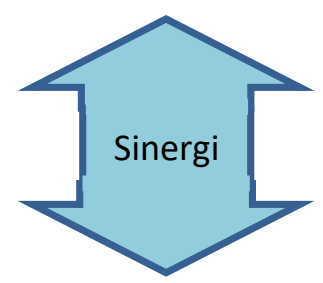

Ekonomi Kerakyatan berazazkan nilai pancasila: Ketuhanan; kemanusiaan; persatuan/ kekeluargaan; musyawarah; keadilan sosial
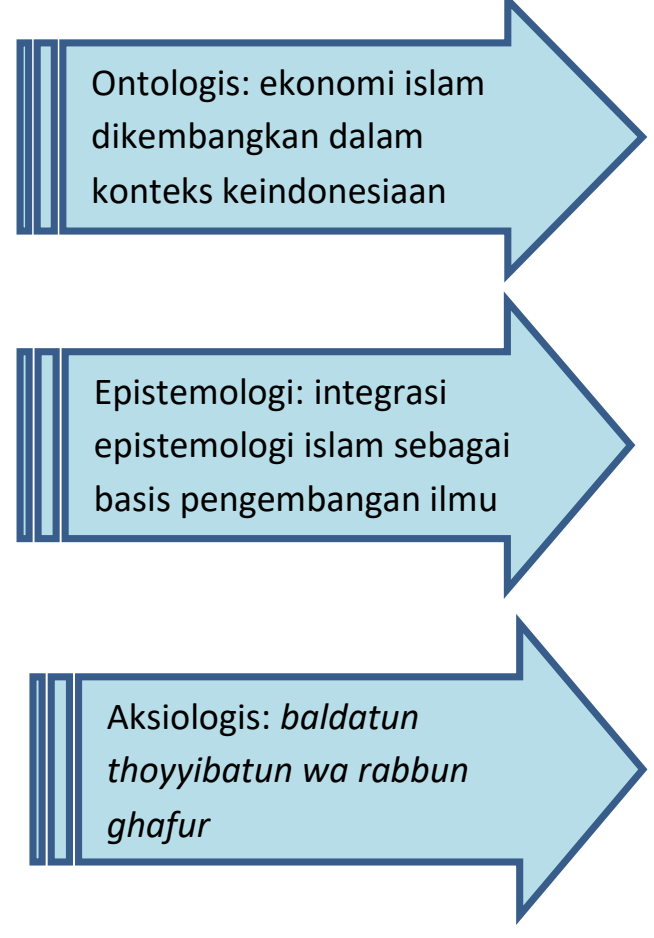

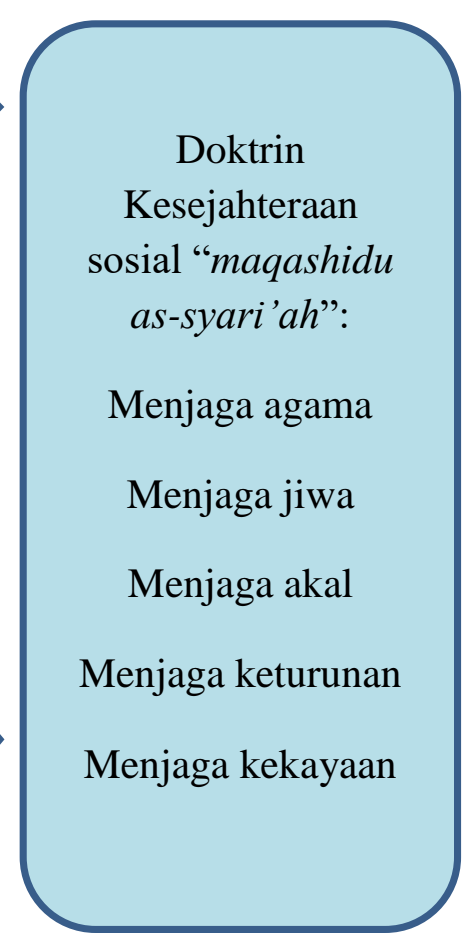

Sumber: Data Primer, 2021

Ekonomi Islam yang dikembangkan di Indonesia sebagai sebuah system sering disebut dengan ekonomi Syariah. Penyebutan Ekonomi Islam atau Ekonomi Syariah pada prinsipnya memiliki alas an yang kuat dan ilmiah. Menggunakan sebutan Ekonomi Islam, bahwa ekonomi merupakan ilmu yang di dalamnya mengatur perilaku masyarakat secara luas dengan berdasar pada akhlak, etika dan moral Islam. Sedangkan penggunaan Istilah Ekonomi Syariah karena sebagai sebuah ilmu yang berdasar pada hokum Islam untuk mengatur tindakan 
pelaku ekonomi apakah sesuai dengan syariat Islam atau tidak.

Dalam mensinergikan antara ekonomi Islam dan Ekonomi Kerakyatan kita lihat prinsip keduanya terlebih dahulu. Prinsip dasar dalam Ekonomi Islam: ketauhidan, keadilan, keseimbangan, kebebasan, dan tanggungjawab. Sedangkan prinsip ekonomi kerakyatan yang sesuai dengan nilai pancasila adalah: Ketuhanan; kemanusiaan; persatuan/ kekeluargaan; musyawarah; keadilan sosial. Kedua prinsip tersebut apabila digabungkan menjadi: ketauhidan (ketuhanan), keadilan (keadilan sosial), keseimbangan (kemanusiaan), kebebasan (musyawarah), persatuan (kekeluargaan), dan tanggungjawab. Dapat dijelaskan lebih rinci bahwa di dalam melakukan kegiatan ekonoi (produksi, distribusi dan konsumsi) berdasar pada prinsip berikut ini:

a. Kegiatan ekonomi yang dilakukan selalu didasari dengan niat yang baik dan mencari ridha Allah. Dan pelaku ekonomi merasa bahwa setiap yang dilakukannya pasti Allah melihat dan mengawasi. Contoh dalam transaksi ekonomi ada beberapa hal yang dilarang yaitu: maisir, gharar, riba, tadlis, talaqqi rukban, dan ihtikar. Karena dalam unsur unsur tersebut walaupun pihak lain tidak mengetahui tetapi Allah pasti maha mengetahui.

b. Keadilan atau keadilan sosial adalah memperlakukan diri sendiri atau orang lain dengan adil, sesuai dengan porsi dan kadarnya.

c. Keseimbangan (kemanusiaan): menyeimbangkan antara kepentingan pribadi dan golongan (kelompok, keseimbangan materi dan non materi, keseimbangan dunia dan akhirat

d. Kebebasan (musyawarah): setiap pelaku ekonomi bebas berpendapat dalam mushawarah untuk menentukan dan menetapkan kemufakatan. Kebebasan di sini tidak mutlak, artinya tetap memiliki batasan dan aturan.

e. Persatuan (kekeluargaan): mempertimbangkan pihak lain ketika melakukan tindakan ekonomi, apakah merugikan atau memberi manfaat dan dampak positif. Mengajarkan nilai nilai kesabaran pada diri sendiri dan orang lain, untuk saling memaafkan, menghargai, dan mentolerasi perbedaan.

f. Tanggungjawab: sebagai khalifah di bumi (warga negara Indonesia) memiliki tanggungjawab terhadap apapun yang dilakukannya, konsekuensinya dia harus siap diawasi oleh orang lain. Setiap yang dilakukan pasti ada reward dan punishmentnya.

Kelima prinsip dasar nilai ekonomi Islam yang disinergikan dengan nilai dasar Pancasila diterapkan di Indonesia dengan memperhatikan kondisi sosial, budaya, politik, geografis dan segala bidang. Bisa diartikan dalam makna yang identic dengan ke-Indonesiaan "ekonomi Islam nusantara".

Tidak hanya menjadikan Islam sebatas nama (label)/ Islamisasi ekonomi di Indonesia. Tetapi menjadikan Islam sebagai sebuha nilai untuk mengembangkan ekonomi di Indonesia. Dengan diterapkannya prisip ekonomi Islam yang disesuaikan dengan kondisi Indonesia dan bukan hanya sekedar label (Islamisasi) maka akan tercipta "Baldatun Thayyibatun Wa Rabbun Ghafur”. Negara yang masyarakatnya Makmur, sejahtera, bahagia, dan merasa aman tinggal di Indonesia. Aman dari tindakan amoral manusia (kejahatan) atau aman dari bencana alam (akibat eksploitasi masyarakat terhadap sumber daya alam yang berlebihan, tanpa aturan).

Tujuan akhir dari proses itu semua adalah kesejahteraan (maslahah dan falah) seluruh lapisan masyarakat. Indicator terwujudnya kesejahteraan adalah indicator maqashidu Syariah. 
2. Sinergi ekonomi Islam dan ekonomi kerakyatan sebagai bentuk transformasi Lembaga

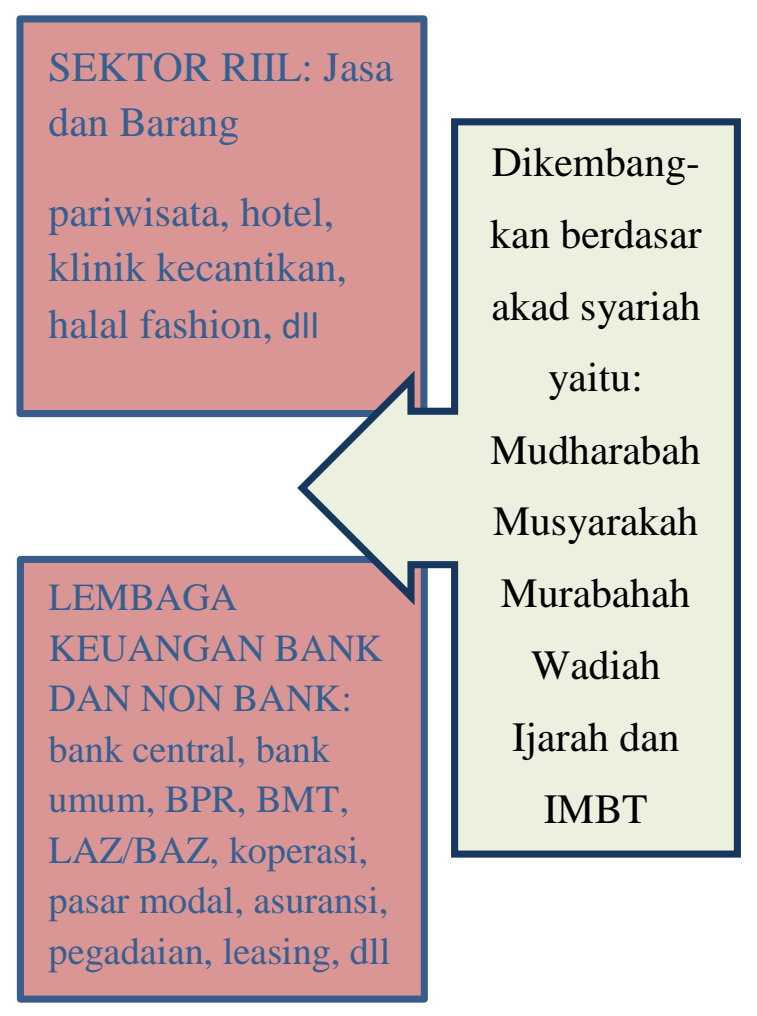

Sumber: Data Primer, 2021

Selama ini yang banyak dikembangkan dengan system ekonomi Islam adalah Lembaga keuangan bank dan non bank. Ekonomi Islam belum banyak menyentuh sector riil. Padahal banyak sector riil (barang dan jasa) di Indonesia yang sangat potensial untuk dikembangkan dengan prinsip Syariah. Diantaranya adalah: fashion, klinik kecantikan, hotel, pariwisata, dan masih banyak sector lain yang dapat dioptimalkan.

Sebenarnya sudah banyak sector riil (barang dan jasa) yang sudah menggunakan label Syariah, tetapi dalam pelaksanaannya masih banyak yang memposisikan Syariah sebatas sebuah label dan trend.

\section{KESIMPULAN}

Dalam kehidupan ekonomi makna transformasi ini adalah berarti mengubah sistem ekonomi yang hanya berorientasi pada profit dan eksploitasi, menjadi system yang mengedepankan beberapa prinsip ekonomi Islam. Transformasi ekonomi Islam disinergikan dengan konteks keindonesiaan yakni system ekonomi kerakyatan. Prinsip dasar dari sinergi ekonomi Islam dan system kerakyatan yaitu: ketauhidan (ketuhanan), keadilan (keadilan sosial), keseimbangan (kemanusiaan), kebebasan (musyawarah), persatuan (kekeluargaan), dan tanggungjawab. Prinsip Islam dalam konteks ke-Indonesiaan dilakukan dalam mewujudkan kesejahteraan masyarakat. Masyarakat hidup di negara dengan sejahtera dan merasa aman.

Ekonomi Islam (ekonomi syariah) yang dikembangkan di Indonesia tidak hanya difokuskan pada lembaga keuangan (bank dan non bank) tetapi juga menyentuh sektor riil. Penerapan prinsip syariah dengan akad akad yang telah ditetapkan, sebagai parameter tingkat ketaatan menjalankan transaksi yang sesuai dengan syariat Islam. Namun demikian Islam atau syariah tidak hanya dijadikan sebagai sebuah label (labelisasi), tetapi lebih dijadikan sebagai sebuah nilai.

\section{DAFTAR PUSTAKA}

Agustiyanti, \& Safyra Primadhyta. (2018). Lika-Liku Jalan Berkerikil Bank Muamalat. ekonomi. https://www.cnnindonesia.com/ekonom i/20180301235151-78-279840/likaliku-jalan-berkerikil-bank-muamalat Akhmadi, S., \& Kholish, A. (2016). PrinsipPrinsip Fundamental Ekonomi Islam. Jurnal Ekonomi Islam (Islamic Economics Journal), 4(1), 97-118.

Arief, M. S. (2001). Ekonomi Kerakyatan. Muhammadiyyah University Press.

Arti kata transformasi-Kamus Besar Bahasa Indonesia (KBBI) Online. (t.t.). Diambil 18 Oktober 2020, dari https://kbbi.web.id/transformasi.

Baswir, R. (2015). Ekonomi Kerakyatan vs. Neoliberalisme. Gema Keadilan, 2(1), 8-17.

Beekun, R. I. (1997). Etika Bisnis Islam: Sebuah Perspektif Lingkungan Global ${ }^{e}$. Jurnal Ulumul Qur'an, VII. 
Chapra, U. (2001). The Future of Economics: An Islamic Perspective. SEBI.

Furqani, H. (2016). Pembangunan Ekonomi Islam dengan Tipologi Ilmiah. Maqdis: Jurnal Kajian Ekonomi Islam, 1(1), 83-96.

Ismawan, B. (2002). Ekonomi Rakyat, Sebuah Pengantar. Jurnal Ekonomi Rakyat, 1 .

Kahf, M. (2003). NOTES ON DEFINITION AND METHODOLOGY. 43.

Karim, A. (2003). Ekonomi Makro Islami Edisi Kedua. The International Institute of Islamic Thought Indonesia, Jakarta.

Malau, N. A. (2016). Ekonomi Kerakyatan Sebagai Paradigma Dan Strategi Baru Dalam Pembangunan Ekonomi Indonesia. Jurnal Ilmiah Research Sains, 2(1).

Mediatama, G. (2020, September 21). Hingga Juli 2020, aset keuangan syariah tembus $R p$ 1.639,08 triliun. kontan.co.id.

http://keuangan.kontan.co.id/news/hi ngga-juli-2020-aset-keuangansyariah-tembus-rp-163908-triliun

Muallimah, S. (2018). Konsep Ekonomi Kerakyatan Mohammad Hatta Dalam Tinjauan Maqasid Syari'ah. Jurnal Investasi Islam, 3(1), 68-95.

Mubyanto. (2002). Membangkitkan Ekonomi Kerakyatan melalui Gerakan Koperasi ${ }^{`}$. Jurnal Ekonomi Islam, 1.

Naqvi, S. N. H. (1981). Etics and Economics an Islamic Syinthesis,. The Islamic Foundation.
Oshodi, B. A. (2013). Integral Approach to Development Economics. Gowerpublishing, 282.

Pangsa Pasar Keuangan Syariah Sulit Imbangi Kinerja Konvensional | Finansial. (2020, Juli 3). Bisnis.Com. https://finansial.bisnis.com/read/202007 03/231/1261245/pangsa-pasarkeuangan-syariah-sulit-imbangikinerja-konvensional

Prawiranegara, S. (1988). Ekonomi Dan Keuangan Makna Ekonomi Islam: Kumpulan Karangan Terpilih 2. Haji Masagung.

Rachman, B. M. (1994). Kontekstualisasi Doktrin Islam dalam Sejarah (Cet.1). Yayasan Wakaf Paramadina.

Rahardjo, M. D. (2015). Arsitekrur Ekonomi Islam Menuju Kesejahteraan Sosial. Mizan.

Rizal, S. (2011). Titik Temu dan Sinergi Ekonomi Islam dan Ekonomi Kerakyatan. Al-Iqtishad: Jurnal Ilmu Ekonomi Syariah, 3(1).

Rohmatika, R. V. (2019). Pendekatan Interdisipliner dan Multidisipliner Dalam Studi Islam. Al-Adyan: Jurnal Studi Lintas Agama, 14(1), 115-132. https://doi.org/10.24042/ajsla.v14i1.468 1

Rustiono, D. (2020). Mewujudkan Sinergi dalam Organisasi. https://unnes.ac.id/gagasan/mewujudka n-sinergi-organisasi

Suhendi, S. (2012). Ekonomi Islam Berbasis Ekonomi Kerakyatan. IQTISHADUNA: Jurnal Ilmiah Ekonomi Kita, 1(2), 299309. 